\title{
Contabilidade financeira as a service: percepções de contadores sobre o futuro das rotinas tradicionais dos escritórios de contabilidade
}

\author{
Maria Andressa Lopes de Araujo - dssaaraujo@gmail.com ${ }^{1}$ \\ Jairo Simião Dornelas - jairo@ufpe.br ${ }^{2}$ \\ Américo Nobre Amorim - Americo@escribo.com ${ }^{3}$
}

\begin{abstract}
Resumo - A contabilidade no Brasil é mandatória e deve ser feita por entidades habilitadas como escritórios contábeis. Nestes, a maior parte das atividades percorre a contabilidade financeira, tradicional, rotineira, regrada e lógica, tanto que é calcada em artefatos computacionais online. Assim, se impõe averiguar nesta época em que se oferta computação em nuvem com sistemática as a service, se aquela modalidade contábil não pode ser transformada em um serviço. Esta foi a trama deste relato, tipo survey, que buscou a visão sobre as rotinas contábeis efetivadas em escritórios contábeis, em formato online, e as postulou como factíveis na forma as a service, no que obteve significativo sucesso. Por fim, especulou se esta sistematização poria em risco a atividade rotinizada nos escritórios, configurando-se como uma ameaça até aos profissionais. Encontrou que há uma tendência à migração sim, mas há retenção de atividades mais cognitivas e analíticas para a rotina do profissional.
\end{abstract}

Palavras-chave: Computação em nuvem, Contabilidade online, Escritórios Contábeis.

\section{Financial accounting as a service: accountants' perceptions about the future of traditional accounting office routines}

\begin{abstract}
Accounting in Brazil is mandatory and must be done by entities authorized as accounting offices. In these, most activities go through financial accounting, traditional, routined, regulated and logical, so much that is based on computer artifacts and runs online. Thus, it is necessary to find out at this time that cloud computing offers practices as a service, if that accounting modality could not be transformed into a service. This was the plot of this survey, a survey that sought the vision about the accounting routines carried out in accounting offices, in an online format, and postulated them as feasible routines as a service, in which it obtained significant success. Finally, he speculated whether this systematization would jeopardize the routinized activity in the offices, setting itself up as a threat to both the professionals and the offices. It found that there is a trend towards migration, but there is retention of more cognitive and analytical activities for the routine of the professional.
\end{abstract}

Keywords: Cloud computing, Online Accounting, Accounting Offices. 


\section{Introdução}

Segundo Medeiros (20I2), a contabilidade, ciência tão remota quanto a civilização, tem passado por diversas fases de progresso através da história e hoje em dia, diante de todas as mudanças e avanços, tem se associado a novas tecnologias angariando novas funções em virtude do ganho de informação e velocidade no desenvolvimento das suas atividades. Mesmo assim, ainda persevera na função de gerar informações que possam ser compreensíveis por seus usuários, possibilitando aos gestores um controle do patrimônio líquido, aumentando a eficiência na tomada de decisão (IUDÍCIBUS; MARION, 2006).

Para isso, a contabilidade utiliza, dentre outras ferramentas, as demonstrações contábeis, que no Brasil, conforme a Estrutura Conceitual para a elaboração e apresentação das demonstrações contábeis, elaborada inicialmente pelo Comitê de Pronunciamentos Contábeis e acatada pela Comissão de Valores Mobiliários através da deliberação ${ }^{\circ} 539$ em I4 de março de 2008 , são preparadas e apresentadas pelo menos anualmente e têm por objetivo atender às necessidades de informações de um vasto número de interessados, sendo, então, consagradas como principais fontes de informações financeiras à disposição dos mesmos.

Neste contexto, entende-se por usuários das demonstrações contábeis, conforme aquela estrutura conceitual, investidores atuais e potenciais, empregados, credores por empréstimos e comerciais, fornecedores, clientes, governos, e suas agências, e, por fim, o público em geral.

Segundo Fedel, Zanchet e Schuck (2009), estes usuários utilizam as informações contidas nessas demonstrações para fins diversos, dentre eles: analisar a capacidade das entidades de pagarem dividendos aos seus acionistas; apresentar informações acerca da estabilidade, lucratividade, liquidez, continuidade e capacidade de pagamento da empresa; demonstrar informações sobre as destinações dos recursos e sobre as atividades da empresa.

Por esta razão, nota-se, então, que a contabilidade e as informações por ela geradas deveriam ser instrumentos de decisão largamente utilizados no contexto organizacional. Entretanto, Iudícibus e Marion (2006) destacam que no Brasil se tem uma visão de que a função do contador é atender às necessidades fiscais, sendo isto mais evidente nas pequenas e microempresas empresas (PME).

Tal visão não mudou muito, como atesta o estudo de Splitter e Borba (20I4), o qual concluiu que as opiniões sobre o contador e a contabilidade são expressas de maneira que nem sempre conferem com o papel do contador ou de sua própria atividade. No rol dessas atribuições, muitas nem pertencem aos contadores, como é o caso de controle de contas financeiras ou organização administrativa da empresa.

Vale ressaltar que vários outros estudos que analisaram nas PME brasileiras, tanto as competências do profissional contábil quanto o uso das informações contábeis (CARDOSO; SOUSA; ALMEIDA, 2006; MEDEIROS, 20I2; RIBEIRO; FREIRE; BARELLA, 20I3), bem como os serviços prestados por escritórios de contabilidade (FEDEL; ZANCHET; SCHUCK, 2009; ALVES et al., 2013; ECKERT et al., 2015), também tiveram como conclusão o fato de que o principal motivo para os gestores contratarem os serviços contábeis é a consultoria fiscal. Já os contadores destacaram como principal necessidade dos seus clientes informações para o recolhimento de impostos e cálculo da folha de pagamento. 
Nesta trilha, itens que geram informações essenciais para o controle dos negócios, como é o caso das informações geradas pelo fluxo de caixa e pelo controle do estoque, não foram destacados com tanta ênfase. Para Fedel, Zanchet e Schuck (2009), o processo de geração dessas informações mais refinadas pode ocorrer basicamente de duas formas: através da criação de um setor específico dentro da organização, responsável pela contabilidade, ou através da terceirização desta atividade, contratando um escritório de contabilidade.

Os escritórios contábeis são sociedades civis, constituídas com o objetivo de prestarem serviços contábeis para outras organizações industriais, comerciais e outras prestadoras de serviços. Para funcionarem comercialmente, tais organizações devem estar registradas junto ao Conselho Regional de Contabilidade (CRC) do estado de sua jurisprudência, bem como estarem sob a legislação do Conselho Federal de Contabilidade (CFC), existindo de acordo com a Resolução CFC n ${ }^{\circ}$ I.098/07 (2007) duas modalidades de organizações contábeis:

- Escritório individual: quando o contabilista, embora sem personificação jurídica, executa suas atividades independentemente do local e do número de empresas ou serviços sob sua responsabilidade;

- Organização contábil: trata-se de pessoa jurídica de natureza civil, constituída sob a forma de sociedade, tendo por objetivo a prestação de serviços de contabilidade.

Nessa perspectiva, Zwirtes e Alves (2015) afirmam que em menos de duas décadas, a sociedade vivenciou tantas inovações tecnológicas que as empresas reduziram a gama de empregados para realizarem serviços administrativos, graças aos sistemas integrados de gestão que lhes permitem, praticamente em tempo real, ter o controle das suas atividades principais, controle esse feito com um número menor de funcionários. Na área de contabilidade este fenômeno também ocorreu, proporcionando alterações, inclusive, nos processos internos dos escritórios contábeis.

Neste ínterim, a computação em nuvem, expressão em português associada à tecnologia cloud computing, representa uma dessas inovações tecnológicas que está invadindo o mundo da contabilidade e transformando o fenômeno da chamada contabilidade online, conforme registros em vários sítios eletrônicos, dentre eles: www.contaazul.com - www.contabilizei.com. br - www.classecontábil.com.br - www.startup.com.

De acordo com Mell e Grance (2009), o Instituto Americano de Padrões e Tecnologia - National Institute of Standards and Technology (NIST) -, a cloud computing é um modelo onipresente para acesso a rede conforme for demandado e conveniente para um pool compartilhado de recursos computacionais configuráveis, os quais podem ser rapidamente provisionados e lançados com mínimo esforço de gerenciamento ou interação com o provedor de serviços. Cinco características são listadas nesta definição: autosserviço sob demanda, acesso a rede de banda larga, pool de recursos, rápida elasticidade e serviço de mensuração.

Segundo Santos (20I6), diante da possibilidade de compartilhar serviços através da Internet, a contabilidade online está ganhando cada vez mais espaço no mercado. Através dela, é possível prestar serviços a empresas distantes da sede de um escritório e atender o mercado tendo uma estrutura enxuta, obtendo grande rentabilidade nos serviços. 
Considerando a construção suscitada, este relato de cunho quantitativo e exploratório-descritivo propôs-se a analisar a percepção dos profissionais contábeis em relação a essa nova perspectiva da contabilidade, a contabilidade online, executada como um serviço em nuvem, as a service, que se utilizada corretamente poderá acarretar em aumento na carteira de clientes dos escritórios contábeis, aumento do faturamento da empresa contábil e, principalmente, na mudança do papel desempenhado pelo profissional contábil nos escritórios de contabilidade.

Buscando atingir tal finalidade, este texto está dividido em seções começando por esta seção introdutória, a qual é complementada com uma breve contextualização do relato. A terceira seção traz uma rápida visita à literatura, buscando resgatar conceitos necessários para uma melhor compreensão e formulação do estudo. A quarta seção abordará o procedimento metodológico usado e fornecerá um caminho para a apresentação dos resultados onde serão arguidas as peripécias conclusivas sobre o recorte pesquisado.

\section{Contexto da pesquisa}

Esta seção procura expor o ambiente e o cenário em que os escritórios contábeis e a computação em nuvem estão inseridos, problematizando-o em relação à postura dos contadores e o papel dos escritórios contábeis, vis-à-vis a emergência da computação em nuvem. Ademais, é também nela que se justifica a realização do trabalho.

\subsection{Ambiente e problemática}

Conforme a prática, os serviços contábeis podem ser prestados por profissionais individuais que atuam em setores especializados dentro das organizações ou por meio de profissionais de escritórios de contabilidade, os quais, segundo Thomé (200I), prestam o seguinte rol de serviços: escrituração contábil, conciliação de contas, elaboração de demonstrações financeiras, declarações fiscais, contabilidade gerencial, dentre outras.

No entanto, com esta configuração de serviços, de acordo com Barros (2005), os escritórios de contabilidade gastam mais tempo com a contabilidade financeira, aquela voltada para as exigências fiscais e legais, em detrimento à contabilidade gerencial, a qual está direcionada para a geração de informações que auxiliam a gestão da empresa, atestando que "na prática, o profissional da área contábil direciona $95 \%$ de seu tempo de trabalho e de seu esforço para o preenchimento de formulários, cumprimento de formalidades legais e apuração de resultados para pagamento de impostos" (BARROS, 2005, p.III).

Ratificando tal compleição, Figueiredo e Fabri (2000) reportam que este cenário operativo restringe a capacidade do escritório contábil no que concerne à oferta qualificada de outros serviços de natureza contábil, tais como: auditoria, perícia, assessoria contábil. A fim de bem executar todas essas atribuições, os escritórios contábeis utilizam sistemas de informação baseados em computador (SI) que coletam, processam, armazenam e distribuem informações destinadas a apoiar a tomada de decisões e a atender às exigências fiscais (ARRAIAL, 20II).

Tal arsenal de software costuma estar atualizado em relação às novas tecnologias da informação (PRADO; BRITO, 20I0), requerendo esforços de atualização constantes às PME e aos escritórios contábeis, em especial devido à constante mudança na legislação e no cenário econômico brasileiro. Isto faz que os custos operacionais se tornem maiores, o que afeta dras- 
ticamente a rentabilidade do negócio, uma vez que essas empresas possuem recursos reduzidos e, em geral, corpo funcional com baixo nível de conhecimento técnico em computação, o que mais uma vez amplia o leque de problemas para atuação.

Neste contexto, uma solução que já fora apontada por Miguel (20II) para as PME, nelas inclusas os escritórios contábeis, seria a substituição da infraestrutura própria de tecnologia da informação (TI) pela infraestrutura ofertada pela nuvem como um serviço, pois à medida que a infraestrutura de banda larga melhora, torna-se possível acessar aplicações maiores e mais complexas em lugares cada vez mais distantes dos grandes centros (DIAS; RODRIGUES; PIRES, 20I2) e este fato configuraria um grande avanço para a execução das atividades contábeis operacionais nos escritórios de contabilidade, pois estes ganhariam tempo e poderiam ampliar suas carteiras de clientes.

Prado, Brito e Cristiani (20I2) afirmaram que o uso de recursos de computação em nuvem é tido como uma alternativa para melhor utilização das ferramentas de TI por PME, pois permite que aplicativos e ferramentas sejam utilizados remotamente sem a necessidade de se tê-los localmente, eliminando ou reduzindo custos com instalação, infraestrutura, manutenção e suporte. Assim, a priori, o uso da computação em nuvem permitiria um baixo investimento com um rápido retorno, desejável para o fluxo de caixa das pequenas empresas.

Focando no âmbito dos escritórios contábeis brasileiros, Hernandes (2015) afirma que a alternativa contábil online, em nuvem, modalidade as a service, reduz custos tanto com TI quanto com funcionários, além de prover economia de escala, uma vez que os empreendimentos que utilizam essa variante tecnológica passam a atender empresas de diferentes estados, cada vez mais distantes, cobrando um valor bem menor do que aquele firmado por escritórios tradicionais, o que beneficia também as empresas clientes.

Não obstante este progresso apontado para os escritórios tradicionais, a tecnologia baseada em processos as a service também se retrata como sucedânea de processo contábil tradicional em escritórios contábeis.

Verdadeiramente, regressando à reportagem publicada no jornal Gazeta do Povo em 20I4, que comentava o aparecimento de uma ferramenta de contabilidade para Internet, desenvolvida em Curitiba, a qual permitia um maior controle das finanças de micro e pequenas empresas, a um custo mais baixo, tem-se um contraponto interessante.

O serviço reportado chamava-se Contabilizei e em pouco tempo já estava presente em cidades como São Paulo, Rio de Janeiro, Belo Horizonte, Porto Alegre e Florianópolis. O software funcionava de forma que o empresário poderia desde abrir sua empresa diretamente pelo site da empresa ofertante, até migrar sua contabilidade para a nuvem preenchendo um formulário virtual. O pacote garantia ao empresário acesso às suas finanças em tempo real, facultando-lhe ainda a emissão diretamente do sítio eletrônico, de notas fiscais eletrônicas, resultando em substancial economia para o contratante do serviço.

Desde então, segundo o Startupi ${ }^{\circledR}$, um site que trata de assuntos relacionados às inovações, tecnologias e negócios, a contabilidade online chegou ao mercado para substituir escritórios contábeis, em especial em rotinas bem definidas e convencionais como a contabilidade financeira, dispensando o contador convencional e seus afazeres tipificados, uma vez que 
ferramentas prometem ser complementares e integradas a plataformas as a service de gestão financeira em empresas tais como: ZeroPaper, Conta Azul, Granatum e Superlógica.

Santos (20I6) afirma que plataformas as a service como as supracitadas, reutilizam o que o cliente já digitou e faz a contabilização da movimentação financeira e a conciliação dos dados, exportando dados consolidados para a atividade contábil (em escritórios ou em desempenho individual), gerando, consequentemente, um ganho de produtividade.

Assim, supõe-se que serviços de contabilidade online operando em plataformas as a service facilitem à implementação da contabilidade financeira e o trabalho do contador, mas de certa forma mudem a percepção do papel deste profissional perante seus clientes, afetando ainda drasticamente a configuração tradicionalmente constituída do escritório contábil.

Este aspecto problemático leva a indagar qual seria a percepção dos contadores sobre o efeito das plataformas as a service na rotina operacional dos escritórios de contabilidade e para cobrir tal perspectiva, buscou-se a visão dos próprios contadores em relação ao efeito da proposição as a service nas rotinas operacionais dos escritórios de contabilidade tradicionais.

\subsection{Objetivo e justificativa}

Partindo da ideia acondicionada no que foi exposto anteriormente, a pesquisa se direcionou a rastrear e analisar a percepção dos contadores sobre o efeito da contabilidade ofertada como um serviço em nuvem, as a service, nas rotinas tradicionais dos escritórios contábeis, em especial na contabilidade financeira.

O sentimento fundamental era averiguar aspectos contábeis funcionais impactados, em especial na contabilidade financeira, quando se pensa na aplicação da computação em nuvem como sucedânea da contabilidade online para a contabilidade financeira nos escritórios contábeis, inventariando potenciais mudanças nos aspectos de execução e especulando modificações de diversos graus de intensidade nas atividades e papel funcional do contador neste novo cenário, em ambientes de escritórios contábeis.

A priori a pesquisa se impôs pela necessidade de se investigar a opinião dos contadores sobre os efeitos da variante as a service nos escritórios de contabilidade, em caráter aplicado, uma vez que estudos similares fixaram-se em avaliar a adoção do uso da computação em nuvem na TI para pequenas e médias empresas, bem como em realizar análises bibliométricas da produção científica sobre os fatores que influenciam as empresas para tal feito (RAMALHO, 20I2; VERDERAMI; ROSA, 2013; VIEIRA; MEIRELLES, 2015).

Ademais, Prado, Brito e Cristiani (20I2), constataram que até o ano da pesquisa realizada por eles, a computação em nuvem ainda não era uma realidade para o ambiente dos escritórios contábeis, e vaticinaram que: "à medida que essa nova tecnologia for evoluindo e se difundindo no mercado brasileiro de TI, muitos escritórios deverão adotá-la". Logo, como não se constatou, até onde se pôde apurar, nenhum trabalho na direção defendida por esta pesquisa, há espaço para executá-la.

No que se refere ao mercado contábil, a justificativa para o estudo reside no fato de que a contabilidade online por meio de uma plataforma as a service soluciona, de modo ágil, simples 
e eficiente todos os tipos de obrigações contábeis comuns no dia a dia do mercado corporativo, além de viabilizar o atendimento a clientes de várias cidades diferentes.

Por fim, mas não menos importante, pelo ângulo da tecnologia da informação, este trabalho se justifica por identificar os modelos de serviços em nuvem e implantação escolhidos pelas empresas e as estratégias quando da sua adoção e utilização.

A seguir é apresentado o relato da visita à literatura realizada neste enredo, destacando os principais conceitos e definições, que interessam ao presente estudo e permitem uma melhor compreensão dos seus objetivos.

\section{Visita à literatura}

Esta seção procura expor o que a literatura traz sobre os principais aspectos desta trama. Para tal, menciona escritórios contábeis e a TI e sua computação em nuvem, adornando a contabilidade como produto as a service.

\subsection{Contabilidade}

Segundo o sítio eletrônico da American Accounting Association, o objetivo da contabilidade é fornecer informações que sejam potencialmente úteis para a tomada de decisões econômicas que resultem no bem estar social.

No que diz respeito ao objeto de estudo desta ciência, Marion (2009), a seu termo, alega que a contabilidade é comumente conhecida como a ciência que estuda o patrimônio, sendo o instrumento que fornece informações úteis para tomada de decisões dentro e fora da empresa.

Com mais foco comenta-se que a função da contabilidade é "captar, registrar, acumular, resumir e interpretar os fenômenos que afetam as situações patrimoniais, financeiras e econômicas de qualquer ente" (FEA/USP 1998, p. 2I), a qual busca, "probabilisticamente, minorar o grau de incerteza em relação à tomada de decisões, por meio de um sistema informacional que dá qualidade racional à tomada de decisão" (PETERS 2004, p. 7).

Para o CPC (2008), as informações contábeis proferidas segundo a égide do pronunciamento conceitual elaborado por este órgão visam fornecer informações de qualidade para os usuários em geral, não havendo, portanto, propósito de atender finalidade ou necessidade específica de determinados grupos de usuários.

A princípio atrelada a qualquer entidade pública ou privada, a contabilidade pode ser dividida em dois grupos principais: a contabilidade financeira e a contabilidade gerencial. A primeira volta-se para a divulgação de informações para as partes externas à organização, como os acionistas; e a segunda envolve o fornecimento de informações para os gerentes que irão fazer o uso dentro da própria organização (GARISSON; NOREEN; BREWER, 20I3).

Em sequência, a próxima etapa do texto descreverá os dois principais segmentos da contabilidade ordinária. Ambos os segmentos distinguem utilizar a contabilidade como fonte básica no processo decisório, mas, não necessariamente, da mesma forma. 


\subsubsection{Contabilidade financeira}

A contabilidade financeira é parte do sistema que provê informações para usuários externos e é orientada pelos princípios geralmente aceitos da contabilidade (HANSEN; MOWEN, 1997).

Operativamente, de acordo com Atkinson et al. (2008), a contabilidade financeira é o processo que gera os demonstrativos financeiros para públicos externos, como acionistas, credores e autoridades governamentais, entidades estas que definem padrões, regulamentações e impostos que limitam a contabilidade financeira.

Configura-se, pois, segundo Laurentino et al. (2008), como uma vertente da contabilidade geral, tendo esta nomenclatura em função de um dos seus principais propósitos: elaborar e fornecer relatórios e demonstrativos financeiros ao público externo.

Conclui-se que a contabilidade financeira tem por objetivo demonstrar por meio de relatórios a situação econômico-financeira e patrimonial da empresa, sempre com base em informações históricas, dando ênfase ao desempenho passado e é normativa, atendendo parâmetros expressos na legislação vigente. Este caráter a torna muito aderente ao regrado e lógico ambiente de processos e regras de negócio, bastante típico da área de TI e SI.

\subsubsection{Contabilidade gerencial}

A seu turno, a contabilidade gerencial constitui-se na parte do sistema contábil que se dedica às informações para os usuários internos da entidade (HANSEN; MOWEN, 1997). Conceitualmente, seu propósito mor "é orientar decisões mediante o fornecimento de informações para a tomada de decisões de caráter corrente e as de natureza estratégica, permitindo também efetuar avaliações de desempenho e fixação do preço de venda baseado no custo, no mercado e no concorrente" (ATKINSON et al., 2008, p. 36).

De acordo com Neves e Viceconti (1998), a contabilidade gerencial é abrangente e concisa, pois não se atém apenas às informações, desenvolvidas dentro da contabilidade, mas também se ampara em outros campos do conhecimento como a administração financeira e a estatística, ajustando-se constantemente para se adaptar às mudanças tecnológicas e das necessidades dos gestores e a novas abordagens das outras áreas funcionais dos negócios (LOUDERBACK et al., 2000). Neste caso, torna-se menos susceptível ao forte regramento e à lógica contundente dos sistemas e soluções informatizadas.

Ademais, conforme Souza e Santos (2005), o principal meio de controle que dispõe uma administração é a contabilidade, a qual disponibiliza como meios de controle interno, um rol de registros e instrumentos de organização administrativa. Estes documentos auxiliam aqueles que exercem função direta ou indiretamente relacionada com a organização, o patrimônio e o funcionamento da empresa (FRANCO; MARRA, 1982).

Neste rol de controles, para Sá (2002; 2009), Hoog (2009) e Costa (20I4) incluem-se atividades bem mais cognitivas e dependentes da perspicácia profissional do contador, como a auditoria, que busca dentro dos fatos e atos contábeis e administrativos, a relação que estes têm com a realidade, identificando, assim, possíveis indícios de erros e fraudes. 
Estas atividades compõem o portfolio dos saberes dos contabilistas e têm se tornado desde sempre e cada vez mais indispensáveis à administração e ao controle de qualquer tipo de organização (LAURENTINO et al. 2008). Por esta última razão, os imprescindíveis serviços contábeis podem ser prestados por profissionais que atuam em setores especializados dentro das organizações ou por meio de profissionais de escritórios de contabilidade, ou seja, empresas contábeis, ao menos na tradição e contextos usualmente concebidos e estabelecidos.

\subsection{Os escritórios contábeis}

Dado ao fato que a legislação obriga as empresas constituídas a possuírem um contador, Artigos I.I79 e I.I82 do código civil brasileiro (CCB, 2002), que se responsabilize pelas informações contábeis, inclusive pelo repasse das obrigações acessórias ao governo, surgem a possibilidade de atuação interna na atividade ou de terceirização para escritórios contábeis.

Os escritórios contábeis são sociedades civis (PRADO; BRITO, 20I0) que, ao que indicam Figueiredo e Fabri (2000), prestam serviços contábeis específicos, alguns dos quais já automatizados. Dentre os serviços prestados, Thomé (200I, p. 2I) relaciona "consultoria, contabilidade, administração de pessoal, escrituração fiscal, expediente (ou serviços comerciais), auditoria, perícia e assessoria". Em geral, é por esta gama de atividades, para Thomé (200I), que as funções são departamentalizadas nos escritórios de contabilidade.

Ademais, pela pressão governamental por informações é que o departamento fiscal passa a ser considerado aquele que oferece maior risco às organizações contábeis, devido às elevadas penalidades impostas pelo poder público aos contribuintes que não entregam nos prazos as guias dos seus impostos e obrigações acessórias calculadas pelo escritório contábil.

Com base no quadro I, verifica-se que os escritórios contábeis prestam serviços sob constante pressão e buscam organizar-se em rotinas sistemáticas para atender as necessidades governamentais e dos clientes, e para tanto dispõem de tecnologia amparada em sistemas.

Quadro I - Serviços prestados por escritórios contábeis.

\begin{tabular}{|l|l|}
\hline Classe de serviço & Serviço prestado \\
\hline Contabilidade & Escrituração contábil e fiscal e expediente (ou serviços comerciais) \\
\hline Assessoria e Consultoria & Contábil, tributária, trabalhista e operacional \\
\hline Auditoria e Perícia & Contábil, tributária, trabalhista, de estoque e operacional \\
\hline Análise econômica e financeira & $\begin{array}{l}\text { Análise vertical, horizontal, de custos e financeira de resultados; relatórios } \\
\text { gerenciais }\end{array}$ \\
\hline Planejamento contábil & $\begin{array}{l}\text { Elaboração de orçamento-programa, retificações, suplementações orçamentárias } \\
\text { e orçamento empresarial }\end{array}$ \\
\hline Outras demandas & $\begin{array}{l}\text { Declaração de IRPF, encerramento de balanços, preenchimento de cadastro, } \\
\text { administração de pessoal }\end{array}$ \\
\hline
\end{tabular}

Fonte: Adaptado de Figueiredo e Fabri (2000).

\subsection{A tecnologia da informação em escritórios contábeis}

A tecnologia da informação surgiu em meados de 1960 e, desde então, gradativamente permitiu implementar complexos sistemas de informação que se constituem em importantes ferramentas de auxílio à tomada de decisão, na busca pela eficiência e eficácia dos processos 
empresariais (ATTARAN, 2004; LOPES; COSTA, 2006).

No cenário então constituído, a TI é percebida como necessidade estratégica, capaz de gerar vantagens competitivas a quem a utiliza em seus negócios e de gerar desvantagens competitivas a quem não a utiliza (LUNARDI; DOLCI; MAÇADA, 20IO). Com esta diretriz, os escritórios de contabilidade usam a TI para criar novos serviços ou para melhorar os serviços prestados a seus clientes, através de SI que desempenham papel relevante, principalmente, na agilidade e confiabilidade (DIAS; RODRIGUES; PIRES, 20I2).

Lunardi, Dolci e Maçada (2010) afirmam que apesar de existirem dificuldades, boa parte das atividades de um escritório contábil pode ser automatizada por software disponível no mercado. O mesmo trio afirma que os clientes do escritório contábil, em sua grande maioria, são pequenas empresas que não possuem sistemas próprios e, às vezes, nem infraestrutura, e necessitam interagir com sistemas existentes nos escritórios contábeis.

Este pormenor faz com que exista retrabalho e digitações excessivas para cessão de informações e isto implica em atraso na divulgação de relatórios. Além disso, a TI não é utilizada para efetuar tarefas relacionadas às atividades de tomada de decisões (LUNARDI; DOLCI; MAÇADA, 20Io). É justo este ponto que possibilita antever o uso da computação em nuvem como alternativa viável para solver este imbróglio.

$\mathrm{Na}$ vertente técnica, o mercado de computação elegeu como mais forte representante para a informática empresarial, os sistemas integrados conhecidos pela alcunha de Enterprise Resource Planning, os chamados ERP, atribuindo-lhes como objetivo fundamental a integração, consolidação e aglutinação de todas as informações necessárias para a gestão do sistema empresa (LAUDON; LAUDON, 20I5). Ainda nesta onda, Colangelo Filho (200I) e Padoveze (2004) apregoavam o conceito de sistema integrado de gestão empresarial (SIGE), como solução para a maior parte dos sistemas de informações necessários para as empresas contábeis, incluindo a produção e uso de informações em tempo real.

Adaptando esta máxima aos escritórios contábeis, Prado, Brito e Cristiani (20I2), apresentam duas categorias de SIGE que se sobressaem: Sistemas de produção, que servem para entregar as obrigações acessórias ao governo, bem como sistemas de administração básica úteis para gerar relatórios gerenciais para a tomada de decisão de seus clientes e Software de gestão do escritório contábil: nessa vertente encontram-se software que controlam o serviço do escritório, o faturamento e também o fluxo de documentos que são entregues ou recebidos.

Em adição, com a maior velocidade e disponibilidade de acesso à Internet e o avanço tecnológico crescente, muitas empresas, inclusive as PME, passaram a utilizar a computação em nuvem. Neste tipo de computação é possível armazenar dados na rede (a nuvem) e usar software e hardware sem precisar instalá-los localmente (VERAS, 20I2).

Muitas das empresas estão aderindo a essa tendência devido a um menor custo que esse serviço proporciona ao invés de investir em uma ampla infraestrutura de tecnologia da informação dentro da empresa (DIAS; RODRIGUES; PIRES, 20I2). 


\subsection{A computação em nuvem}

A computação em nuvem apresenta-se como o cerne de um movimento de profundas transformações do mundo da tecnologia (TAURION, 2009), por representar um novo conceito computacional, no qual serviços de TI são fornecidos no sentido de sua utilidade, por terceiros, e pelo qual os usuários têm transformado a sua infraestrutura, em uma abordagem de computação orientada a serviço - as a service (KARTHIKEYAN; SUKANESH, 20I2).

Dias, Rodrigues e Pires (20I2) afirmam que quando se faz a migração para uma nuvem, não é necessária a compra de novos equipamentos, o que diminui muito os custos com tecnologia. Estes mesmos autores dizem que outro ponto a favor da computação em nuvem, está no fato de que os empregados de uma empresa poderem ter acesso aos dados da mesma, com uma simples conexão à Internet.

Ora, sendo a computação em nuvem um conjunto de recursos virtualizados de fácil acesso (VERDERAMI; ROSA, 20I3), é um serviço que pode ser prestado de diferentes formas, que tem como base três estruturas básicas diferentes:

- Software as a service (SaaS): nesta modalidade um aplicativo é passado como um serviço aos clientes que o utilizam pela Internet. $\mathrm{O}$ aplicativo fica inteiramente na nuvem (RUSCHEL; ZANOTTO; MOTA, 20IO);

- Platform as a service (PaaS): neste caso, os fornecedores concedem ambientes virtuais, incluindo sistemas e linguagens de programação, propícios para o desenvolvimento de aplicações pelos clientes (LYER; HENDERSON, 20IO);

- Infrastructure as a service (IaaS): onde são oferecidos servidores dedicados para acesso e controle total do cliente, que pode armazenar, manipular suas informações e proceder a instalação de aplicativos e sistemas operacionais de acordo com suas necessidades (RYAN; LOEFFLER, 20IO).

Para as PME, em geral, o IaaS é a opção que propõe mais ofertas (TAURION, 2009), pois o cliente pode alugar recursos e faturá-los com base na utilização. Também soa como vantajoso o desapego de software local, ou seja, não é mais necessário ter a contratação de software para cada computador, é preciso somente de uma cópia, que está na nuvem.

Por fim de vital relevância aos intentos deste relato, a modalidade PaaS utilizada pelos escritórios online (HERNANDES, 20I5, p. I), "torna acessível um conjunto de funcionalidades que resolvem grande parte da rotina administrativa de um negócio, disponibilizando recursos como emissão de nota fiscal eletrônica, controle de resultados da empresa e guias online de impostos".

\subsection{A contabilidade como um serviço em nuvem}

A prestação de serviços contábeis por meio de canais eletrônicos é uma inovação de sustentação, que busca melhorar os processos de prestação de serviços, com uma estratégia de melhoria, visando reduzir custos e agilizar o atendimento ao cliente. Trata-se, pois, de uma inovação nos canais de atendimento para sustentar um modelo de negócios tradicional, que 
trilha um caminho parecido com aquele empreitado pelas instituições financeiras na década de I990, rumo à automação bancária (FONSECA; MEIRELLES; DINIZ, 20Io).

Para Hernandes (2015), e com forte endosso do mercado brasileiro, a contabilidade em nuvem oferta-se de forma que o cliente faz a parte operacional, como, por exemplo, lançamentos, conciliações bancárias, protocolo de documentos em órgãos públicos; e o escritório que opera com a contabilidade online fornece todo o suporte das informações contábeis, a partir das demonstrações e consultorias para tomadas de decisões com as mesmas, fazendo assim com que o cliente ganhe com a economia de um serviço mais barato. O contador, nesse caso, assume papel mais gerencial auxiliando o gestor na tomada de decisão.

Para Duarte (20I6), os escritórios contábeis com modelos de negócios consolidados e atuação já segmentada têm grandes chances de serem beneficiados por este movimento, pois podem (e devem) usar meios eletrônicos como forma de melhoria dos processos e relacionamento com clientes, sem negligenciar os canais presenciais. Entre as principais vantagens de contratar os serviços deste tipo de escritório online estão a economia de tempo e dinheiro e a qualidade do atendimento, além da acessibilidade e de baixo tempo de resposta.

De acordo com Ricini e Zanchet (2008), as empresas que optavam pela contratação dos serviços de um escritório de contabilidade se mostravam satisfeitas com a escolha e atribuíam à contabilidade terceirizada, funções definidas pela literatura contábil, entre as quais: rotinas trabalhistas, consultoria fiscal e previdenciária e alterações contratuais. À época da pesquisa, contabilidade financeira, contabilidade gerencial e conciliação contábil, que são atividades que visam atender ao objetivo de fornecer informações úteis e relevantes que auxiliem o processo de tomada de decisão, foram pouco citadas como tarefas transferíveis.

Assim torna-se factível auscultar, mais de dez anos depois, se a possibilidade de execução dessa forma de contabilidade descentralizada, realizada na forma de um serviço em nuvem, modificou aquelas constatações (como se crê), incorporando ao leque básico já estabelecido, estas funções metodizadas que antes estavam fora do escopo.

Este é o ponto que esse trabalho visa detectar: a visão dos contadores em relação à trama de avaliar se a contabilidade online em nuvem é fonte para que os escritórios contábeis sintam-se abalados na execução da contabilidade financeira e passem a esmerar em seus contadores e em suas ações o direcionamento à função gerencial.

Como encerramento dessa visita à literatura, alguns componentes da trama conceitual da pesquisa foram destacados, com a finalidade de evidenciar a forma operacional que o trabalho foi realizado, a fim de alcançar os objetivos traçados. A isto se chamou de modelo operacional de pesquisa, destacado na figura I, mesmo que nele constem itens não comentados neste texto. 
Figura I- Modelo operacional da pesquisa.

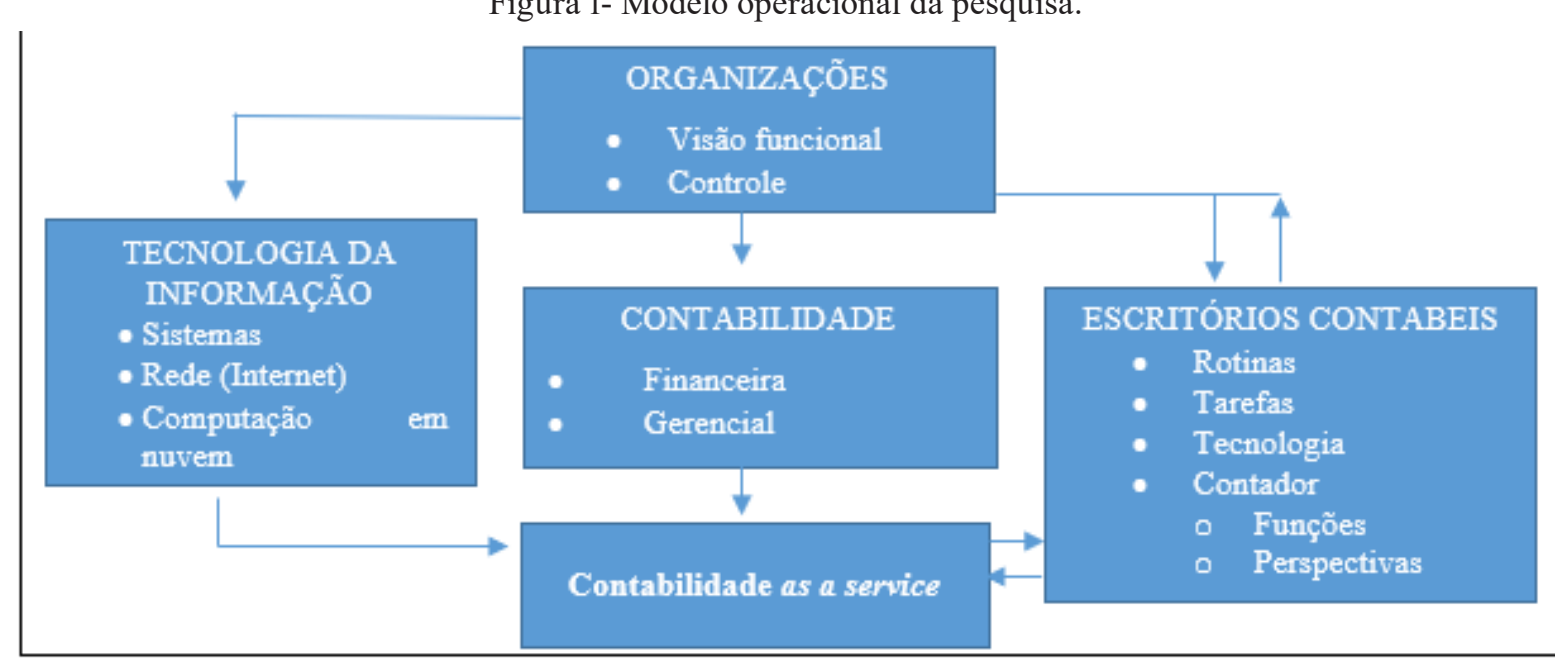

\section{Procedimentos metodológicos}

Os métodos de pesquisa são "procedimentos gerais que norteiam o desenvolvimento das etapas fundamentais de uma pesquisa científica" (ANDRADE, 200I, p. I30). Para Prodanov e Freitas (2013), os procedimentos de pesquisa configuram-se como um conjunto de processos e operações mentais empregados na pesquisa, bem como a forma de pensamento utilizado para compreensão dos fenômenos.

Assim, o presente relato credita-se a figurar como um exercício dentro do método dedutivo, pois parte de um assunto geral para um específico e enveredando pelos ensinamentos de Collis e Hussey (2005), consiste em uma pesquisa exploratória, que visa, no dizer de Coelho e Silva (2007) e Gil (20I0), desenvolver, esclarecer e modificar conceitos e ideias. Todavia, também se lhe reserva, adágios de natureza descritiva, destacados na mescla de se buscar descrever como os contadores veem a contabilidade as a service.

Como cânone semifinal a entoar, afixa-se com apoio em Guimarães, Martins e Guimarães (2004), que o presente relato tem abordagem quantitativa, vez que de forma sistemática, tenta transformar opiniões e informações em números, a fim de classificá-las e analisá-las, utilizando-se de técnicas estatísticas apropriadas (KAUARK; MANHÃES; MEDEIROS, 20IO; SILVA, 20IO).

Por fim, em se falando da estratégia para condução desta pesquisa na seara das ciências sociais aplicadas, recorre-se ao ensinamento de Yin (2013), para destacar as usuais estratégias de pesquisa: experimental, survey, histórica, documental e estudo de caso; para por opção de acesso ao campo e tratamento analítico, ater-se a estratégia de survey com entrevistas de aprofundamento, como opção para conduzir a pesquisa.

Definidas as opções de cunho teórico neste nível, chega-se ao momento de concepção prática e aí é necessário desenhar o caminho a ser seguido, uma vez que cada caminho poderá levar o investigador a alcançar diferentes resultados, razão pela qual se deve avaliar as restrições e oportunidades colocadas pelo contexto dentro do qual se pretende trabalhar.

Assim o desenho de uma pesquisa é o mapa, o caminho e seus respectivos contornos, 
que a partir de uma questão ou foco norteará a investigação e o alcance dos objetivos traçados previamente (GODOY, I995; MERRIAM, I998) e aquele que se pretende seguir no presente caso está esquematizado na figura 2.

Figura 2 - Desenho da pesquisa.

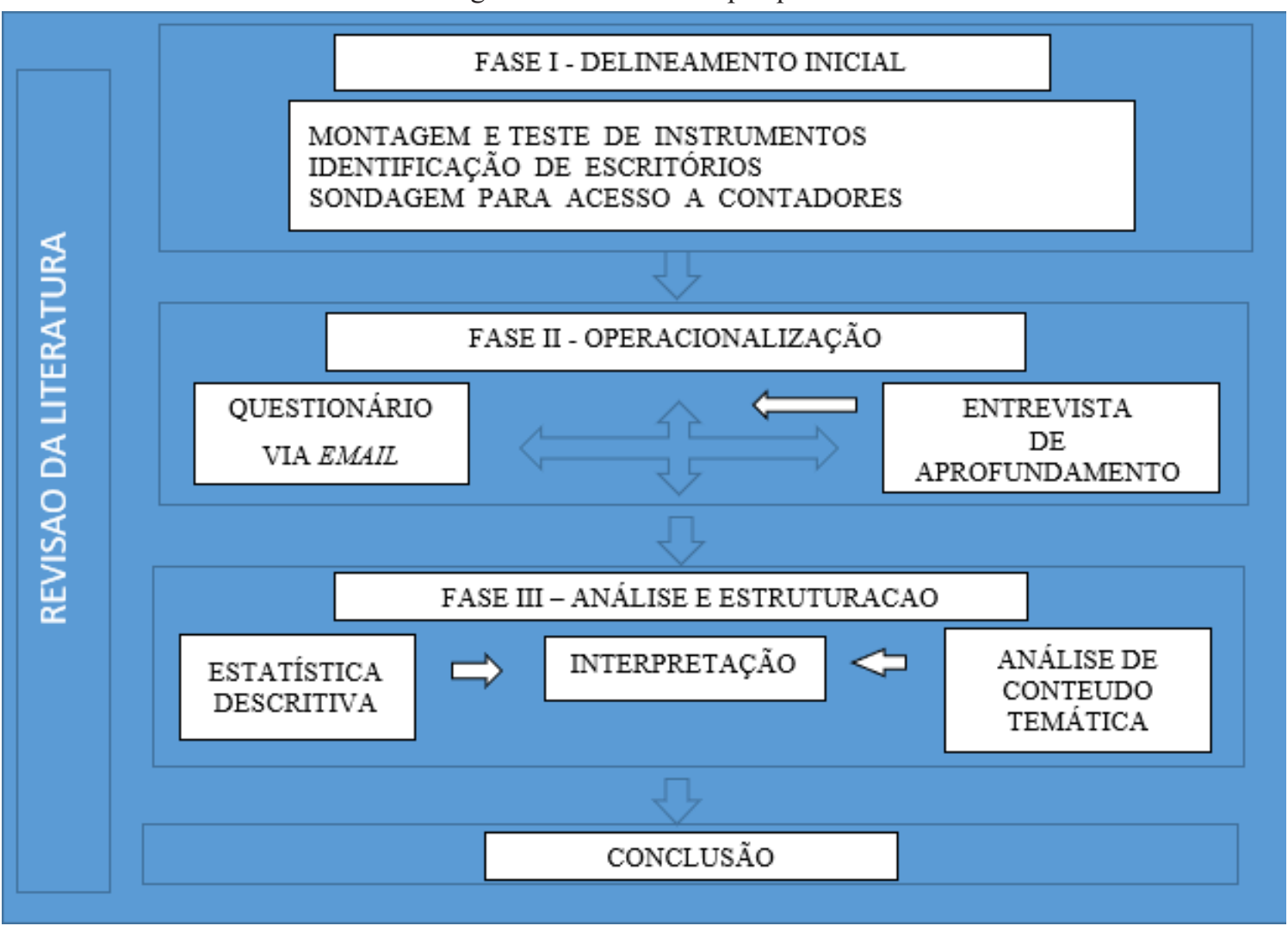

No que diz respeito à instrumentação da pesquisa, em sintonia com sua estratégia e seu método, foi usado um questionário na primeira etapa da coleta de dados e, a posteriori, recorreu-se à entrevista em profundidade com os contadores dos escritórios contábeis.

O questionário consistiu em um conjunto de dados de segmentação (sexo, faixa etária, grau acadêmico e tempo de formação), que era complementado por perguntas sobre as atividades exercidas em escritórios de contabilidade e sobre a execução da contabilidade online e em nuvem, totalizando treze questões fechadas uma questão aberta.

Preliminarmente, os questionários foram pré-testados com cinco contadores e com cinco alunos do mestrado em ciências contábeis, a fim de verificar as possíveis inconsistências (complexidade das questões, imprecisão na redação e itens desnecessários), que o instrumento apresentaria. Os pontos apontados no teste como frágeis ou obscuros foram melhorados.

Os questionários foram enviados a contadores de vários escritórios contábeis, via link do GoogleDocs ${ }^{\circledR}$. O instrumento ficou disponível na nuvem por 37 dias no período de 28/II do ano $\mathrm{X}$ até o dia a 04/oI do ano $\mathrm{X}+\mathrm{I}$.

Por fim, foi efetuada a análise dos dados compilados. O propósito da análise é organizar e sumarizar os dados de forma que estes evidenciem respostas ao problema identificado. Em outra mão, a interpretação consiste em procurar por um sentido ainda mais amplo para os dados, 
ligando-os aos conhecimentos anteriores (GIL, 20IO). Assim, é esperado que a fase de análise de dados responda à pergunta formulada e torne possível o alcance dos objetivos, mediante o emprego das técnicas de análise apropriadas.

Foram obtidas 96 (noventa e seis) respostas válidas. Sobre estas utilizou-se a análise de dados bivariada (REIS, 200I). O objetivo desta escolha foi determinar os tipos de associação sobre a possibilidade de a computação em nuvem estar modificando o teor das rotinas operativas dos escritórios contábeis. As correlações estabelecidas não foram instanciadas em grupo nem sobre elas se fez testes de significância da associação, embora isto pudesse ser feito pelos parâmetros de escolha. Por opção e por emprego de técnica, apenas associações descritivas e de correspondência foram tabuladas.

Também se fez uma exploração livre do conteúdo da única e decisiva questão aberta do instrumento, posto que no roteiro mais amplo do projeto estudado, esta exploração seria guia para a entrevista de aprofundamento.

Não obstante, a fim de que o trabalho fosse conduzido com o máximo rigor metodológico, alguns cuidados foram tomados objetivando preservar a integridade e a confiabilidade da coleta, da análise e do relato, em especial quanto à escolha dos atores e o viés cognitivo da classe e dos pesquisadores.

A seguir são apresentadas as ilações sobre os resultados da coleta e especulados motivos e intenções da pesquisa.

\section{Observando os resultados}

Nesta seção, serão apresentados e discutidos os resultados obtidos na fase da coleta de dados.

\subsection{Análise dos dados de segmentação}

O primeiro enfoque a ser perseguido tratou dos chamados dados de segmentação, a fim de produzir uma visão global da amostra alcançada. Quatro grandes variáveis deram esta compleição a saber: gênero, idade, tempo de formação e experiência. Os dados não trouxeram maiores surpresas em relação aos conjuntos ordinários já estabelecidos na linha profissional:

- Quanto à perspectiva de gênero, a proporção quase em torno de $60 \%$ mulheres x $40 \%$ homens, foi relativamente surpreendente na coleta, em especial se olharmos o escopo profissional atingido, cuja ocupação é majoritariamente voltada a homens;

- A amostra revelou intensa presença de graduados nos escritórios (cerca de 53\%) e um alto percentual de especialistas (em torno de $37 \%$ ), uma mudança de perspectiva segura em relação ao passado de predomínio técnico, na amostra só $3 \%$, que pictoricamente foi igual ao irrisório percentual de pós-graduados strictu sensu;

- Olhando a composição etária destacou-se a presença de maioria de jovens (da faixa até 25 anos) nos escritórios contábeis, quiçá por questões de recrutamento e empregabilidade. Causou estranheza a flutuação nas faixas intermediárias, nas quais se esperava encontrar 
números declinantes, por alcançar profissionais mais bem estabelecidos, e, portanto, distantes dos escritórios pela senioridade amealhada.

Por fim, fechando o exame da identificação notou-se a recência laboral de profissionais de contabilidade nos escritórios (mais de 60\% - abaixo dos cinco anos de formatura), o que daria cobertura à conjectura aventada no segundo tópico. A faixa mais sênior ou não participa da lida dos escritórios ou já está montando seus próprios empreendimentos. Esta última impressão é mais bem caracterizada no gráfico I a seguir.

Gráfico I - Compilação de dados relativos à experiência profissional.

Experiencia profissional dos respondentes

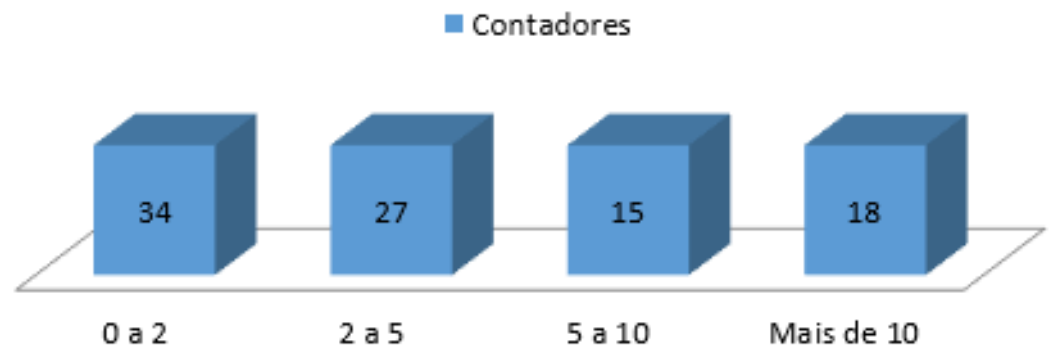

\subsection{A perspectiva da contabilidade online}

Um dos grandes avanços que se presenciou no trato contábil inclusive nos escritórios contábeis, decorre, como visto, da adoção da TI e de seus sistemas. Tecnicamente se pode afirmar que cresceu e tornou-se imperiosa a necessidade de uso de computadores na sistemática online, para melhor executar tarefas e atividades contábeis (BONINI, 20I2). Ressalte-se, em ressalva, que na parte qualitativa, apurou-se um grande embaralhamento entre as noções de ser algo online e se estar usando a Internet.

Avaliou-se então, o que é feito em termos contábeis com suportes informáticos e o quê ocorre com os desdobramentos da adoção destes artefatos computacionais em várias das rotinas contábeis, aqui globalmente taxadas de tradicionais. $\mathrm{O}$ enfoque inicial foi primeiro segmentar as atividades contábeis como atividades executáveis nos escritórios. A questão que foi conduzida aos contabilistas resultou nas respostas acostadas no gráfico 2.

Gráfico 2 - Conjunto de atividades contábeis típicas em escritórios contábeis.

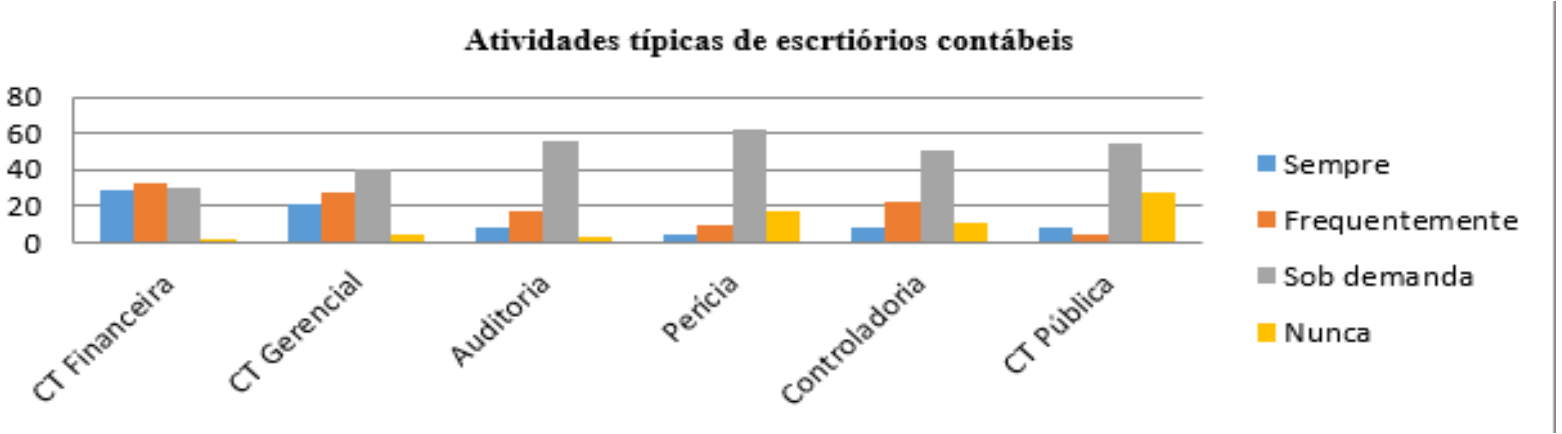

A perspectiva que se revelou foi que embora se tenha a larga noção que as atividades 
ocorrem majoritariamente sob demanda, a exceção da contabilidade financeira, nenhuma delas é estranha ao escopo das empresas - fato esperado - embora a essência das atividades seja de, de fato, como pensado e advogado, sobre a contabilidade financeira. A destacar ainda, o baixo nível de percepção sobre a adequação de executar rotinas sobre a contabilidade pública e a possibilidade relativamente alta de execuções de atividades de controladoria.

Ato contínuo buscou-se apurar qual seria o uso da TI e de seus artefatos para execução da contabilidade online. A definição para contabilidade online em nível acadêmico constava do questionário. A noção precípua era evitar que o respondente associasse o conceito de online exclusivamente ao uso da Internet. Este erro comum, embora goze de notória penetração no mercado, deveria ser coibido para não gerar controvérsias aos interesses da pesquisa.

Nas respostas obtidas, reluziu como extremamente majoritária a alternativa sempre e para todas as opções fornecidas. Ou seja, foi ratificado que o contador reconhece a necessidade do uso da TI em suas tarefas e rotinas funcionais sempre ou frequentemente.

De real interesse para os intentos do relato foi constatar que na amostra se apercebe claramente que as rotinas contábeis mais duras (financeira e gerencial) nunca são exequíveis sem o apoio da TI e neste caso online. O gráfico 3 demonstra as respostas obtidas.

Gráfico 3 - Uso de tecnologia da informação e seus apetrechos na contabilidade online.

Apoio da TI às rotinas - Contabilidade online

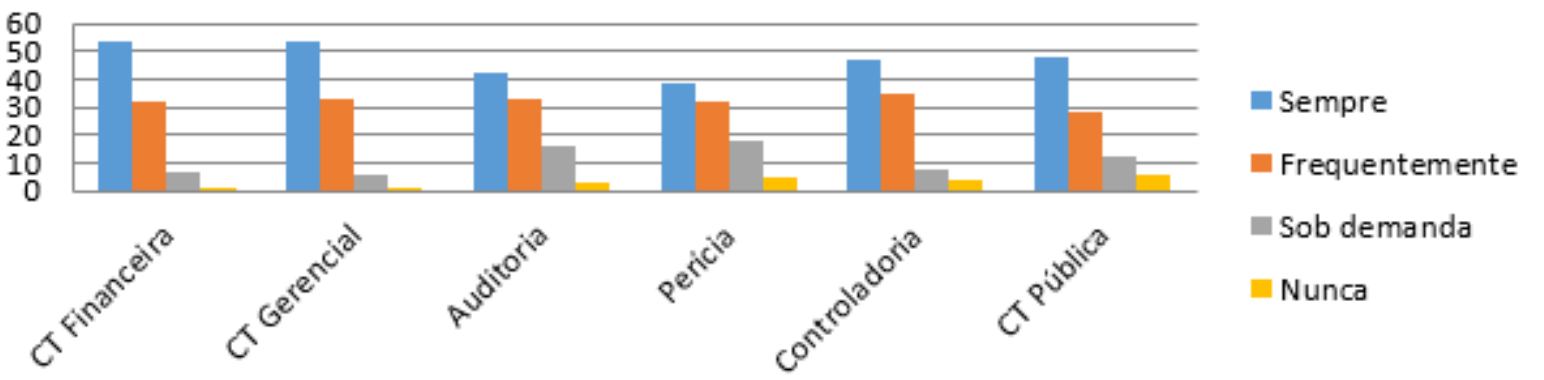

Em se tendo em mente a possibilidade de execução das rotinas contábeis mais tradicionais na perspectiva dos contadores de escritórios contábeis, indagou-se quais das principais rotinas atreladas à contabilidade mais difundida (ações financeira e gerencial) usufruíram da contabilidade online.

Gráfico 4 - As rotinas contábeis típicas e sua adequação à sistemática online.

\section{Possibilidades de execução de rotinas típicas na contabilidade online}

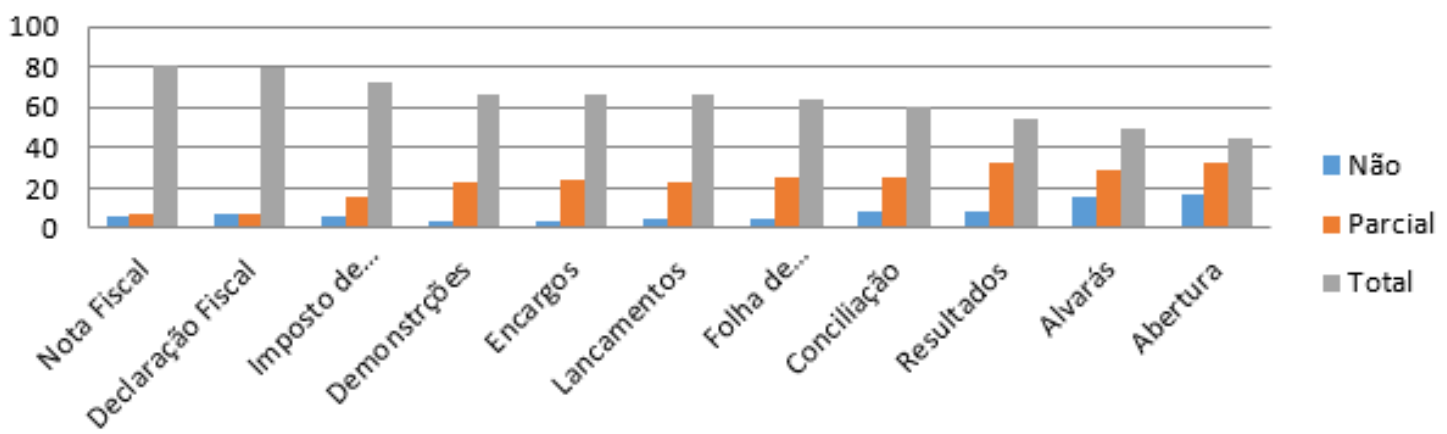


As opções fornecidas possibilitaram um escape da dicotomia, propiciando um ponto equilibrado (parcial). Não obstante esta variante, a opção que prevaleceu disparadamente, quase $50 \%$ em todas as alternativas, foi a opção totalmente factível sob a contabilidade online. A realçar o nível de rotinização presente (contabilidade financeira) nas opções mais ostensivas.

Já que os respondentes ajuizaram a sensação de alta representatividade à contabilidade online, indicando como essencialmente factível para os escritórios, soou apropriado auscultar a amostra sobre quais seriam as benesses de uso da contabilidade online. O questionamento buscou apurar com base nas ilações de Fernandes (2015), quais seriam as vantagens percebidas para os escritórios contábeis, ao adotarem sistemáticas online para execução de rotinas típicas da contabilidade em ambas as perspectivas: da própria empresa e do cliente.

Referenda-se, de certo modo e com surpresa, que as moções de mais evidência se referem às possibilidades de negociação com locais remotos, redução de uso de papel, em prol de uso de mídia digital e integração digital e de etapas contábeis, assinalando positivamente a visão de Veras (20I2), inclusive com o destaque para a negatividade do aspecto segurança de elementos digitais. Os resultados compõem o gráfico 5.

Gráfico 5-Vantagens percebidas pelo uso de contabilidade online nos escritórios contábeis.

Vantagens percebidas na contabilidade online

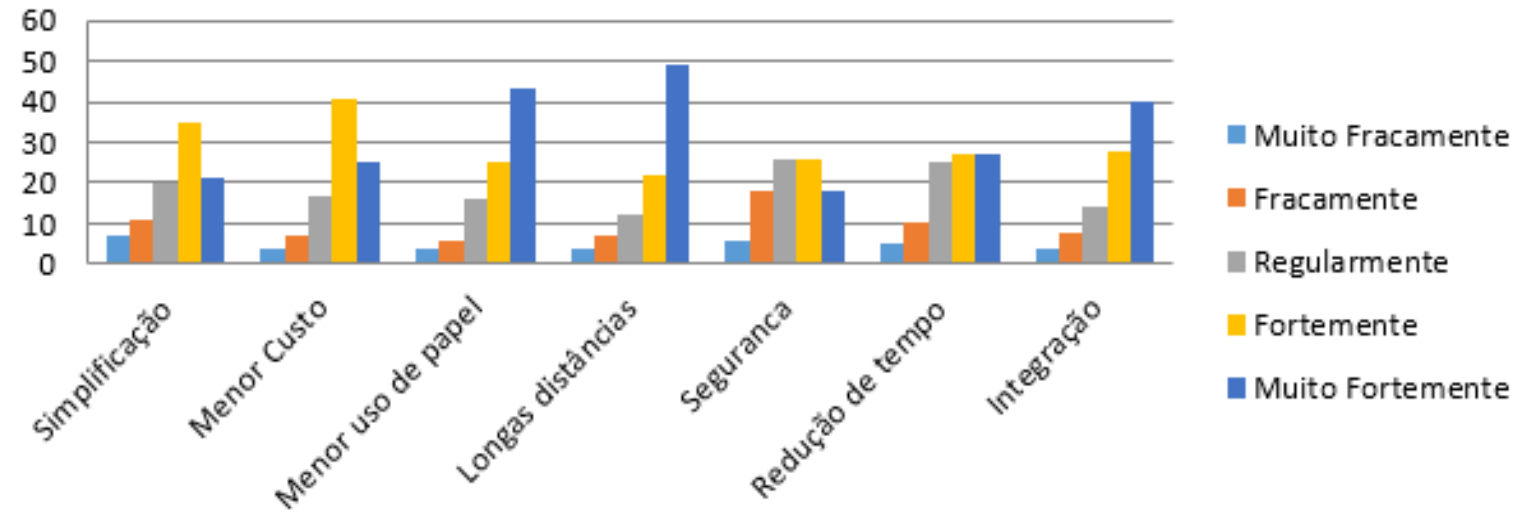

\subsection{A perspectiva da contabilidade em nuvem}

Avançando um pouco para a questão cerne da pesquisa aderente a este relato, buscou-se direta e incisivamente a percepção dos contadores ouvidos, acerca da real possibilidade de a contabilidade ser ofertada como um serviço em nuvem, nos moldes pregados por Mell e Grance (2009). O resultado animador indicou que $80 \%$ dos informantes afirmaram ser admissível a contabilidade ser ofertada na modalidade as a service, como mostra o gráfico 6.

Gráfico 6 - Percepção dos contadores quanto à viabilidade da contabilidade as a service.

Admissibilidade da contabilidade as a service

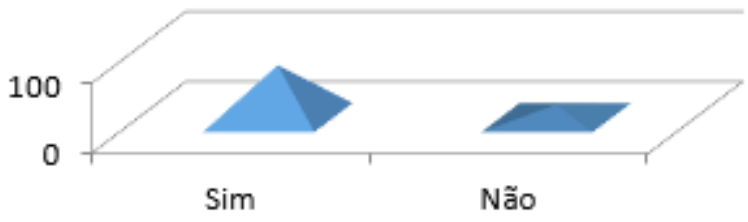


Ora, se a moção de se ter a contabilidade as a service é tão premente na visão dos entrevistados, buscou-se, naturalmente apurar como seria este tipo de execução ao nível de percepção dos contadores de escritórios contábeis alcançados.

Cabe destacar que quando o rol de questões era apresentado ao respondente, o instrumento continha claramente e com apoio da literatura, o conceito tratado. Assim, as noções assumidas a partir do instrumento para os enfoques de contabilidade online e em nuvem era exposta ao ator. Logo, mesmo que restassem resquícios da incerteza entre ação online e via Internet ou destas duas quanto à computação em nuvem, a definição conceitual buscada fora anunciada previamente ao respondente.

Resgatando então a apreciação que o informante teria quanto à possibilidade de execução das rotinas típicas, que já fora buscada para a modalidade online, fez-se o mesmo questionamento sobre as mesmas rotinas, mas agora intuindo o suporte da contabilidade as service, para a execução, em especial a financeira e a gerencial. O resultado compõe o gráfico 7 e nele percebe-se uma distribuição praticamente equivalente de opiniões sobre a possibilidade de execução das rotinas as a service, se confrontadas com a execução online, coincidindo as estimativas de chances de execução em oito das onze rotinas.

Gráfico 7 - Perspectiva de execução das rotinas típicas via computação em nuvem.

Possibilidades de execução de rotinas típicas na contabilidade as a service

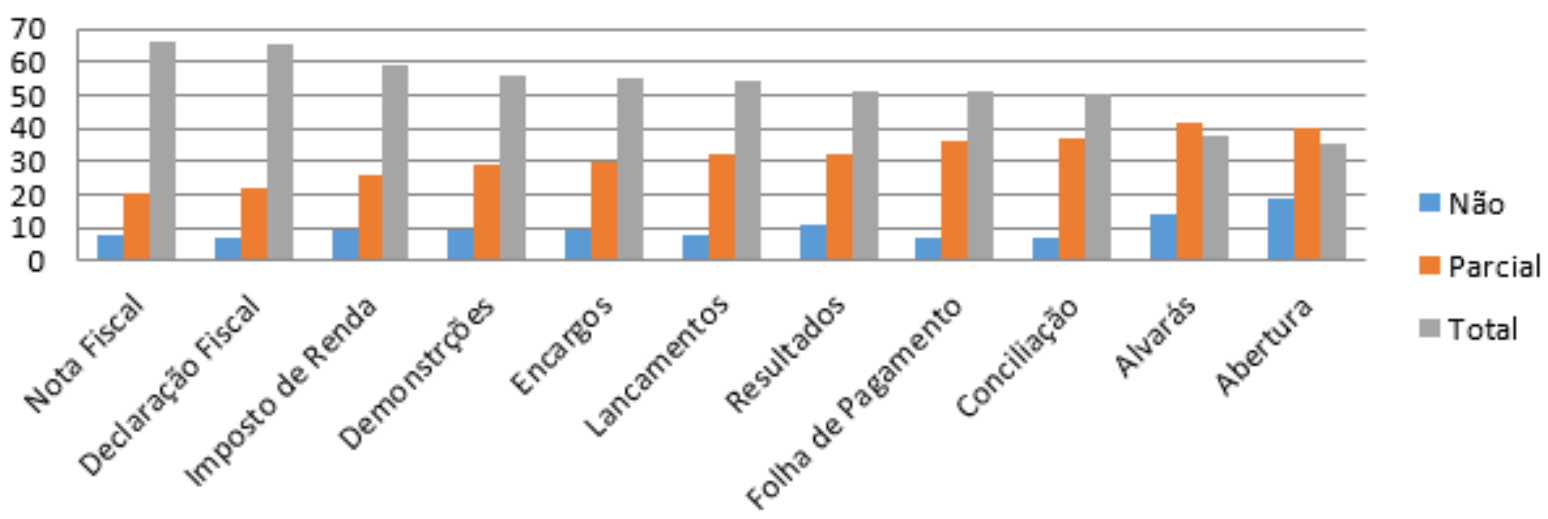

Gráfico 8 - Comparação das chances de execução das rotinas típicas.

Possibilidades de execução das rotinas típicas nas duas modalidades
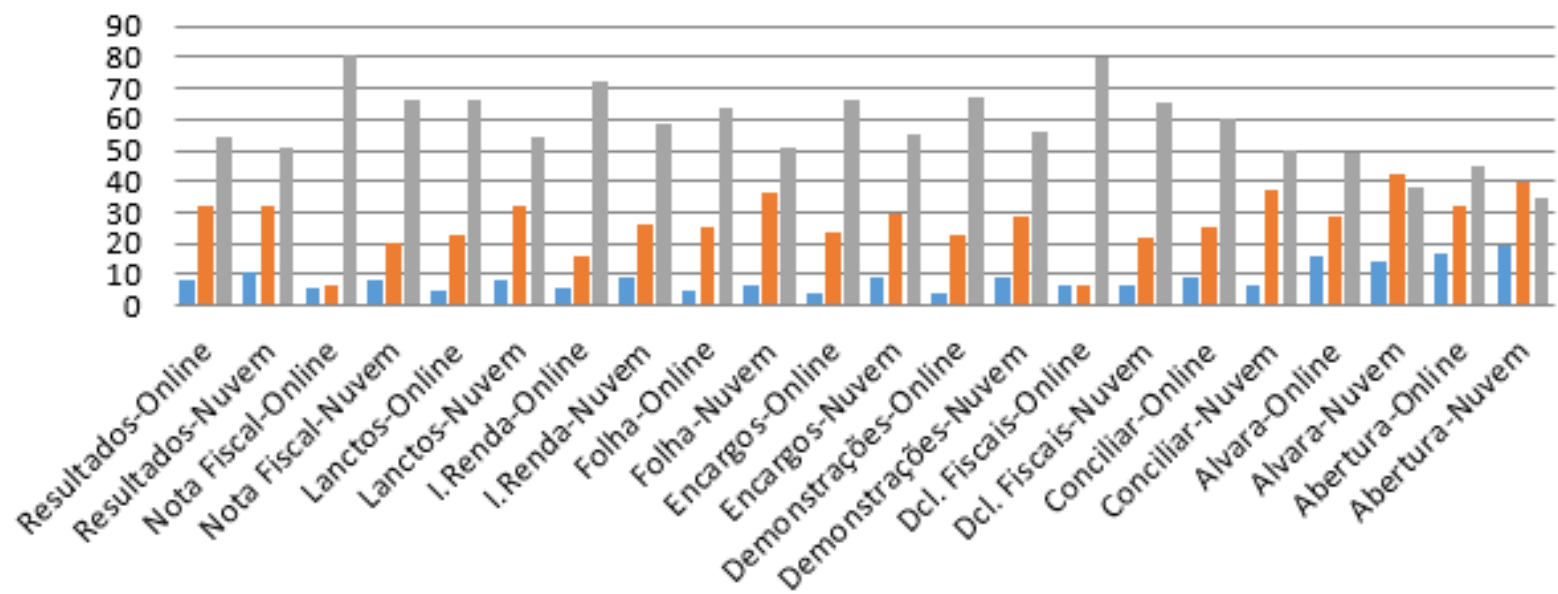

não $\quad$ Parcial $=$ Total 
Percebe-se, pois, no gráfico 7, a sintonia de visão, mesmo que os números de aprovação total soem mais modestos neste segundo caso, e que há uma presença mais evidente da opção possibilidade parcial de execução. Ademais, notadamente, apenas em duas das rotinas a opção parcial, é majoritária (emissão de alvarás e aberturas de firma) e também nessas mesmas é onde a opção de não ser possível executar em nuvem ultrapassa a barreira dos I0\%.

Buscando tornar esta comparação mais incisiva e para retratar a percepção de campo, resolveu-se comparar as onze alternativas construídas e taxadas de rotinas tradicionais (PADOVEZE, 2004), nos dois momentos de inquérito; e para tal traçou-se o gráfico 8. Nele as rotinas são expostas contiguamente e são mostradas as indicações em cada uma das alternativas de resposta em campo. Notar-se-á com um pouco mais de atenção uma similitude muito marcante de opções tanto para online quanto para nuvem, dando a entender que a natureza da execução é mais importante que o veiculo de execução e que a substituição de uma pela outra forma, parece ser uma questão evolutiva.

Em etapa mais avançada do tratamento analítico buscar-se-ão evidências de significativas diferenças entre as métricas, momento em que se tentará esboçar, estima-se, a linha evolutiva delineada. Todavia em havendo a sugestão de que a rotinização as a service poderá ser uma alternativa realística em pequeno espaço de tempo, buscou-se compreender que vantagens esta modalidade traria para a execução da contabilidade, em especial a financeira, no escopo dos escritórios contábeis.

A princípio Bonini (20I2) e Fernandes (20I5) extremam as facilidades típicas de rotinas organizacionais baseadas em tecnologia em termos de artefatos ou modelos de execução como características marcantes. Mais amiúde, Lunardi, Dolci e Maçada (20I0) encaixaram como tipicamente obteníveis os aspectos de agilidade, amplitude, comodidade eficiência e segurança, como elementos a postular em uma boa implementação as a service.

Gráfico 9 - Aspectos organizacionais da implementação da contabilidade as a service.

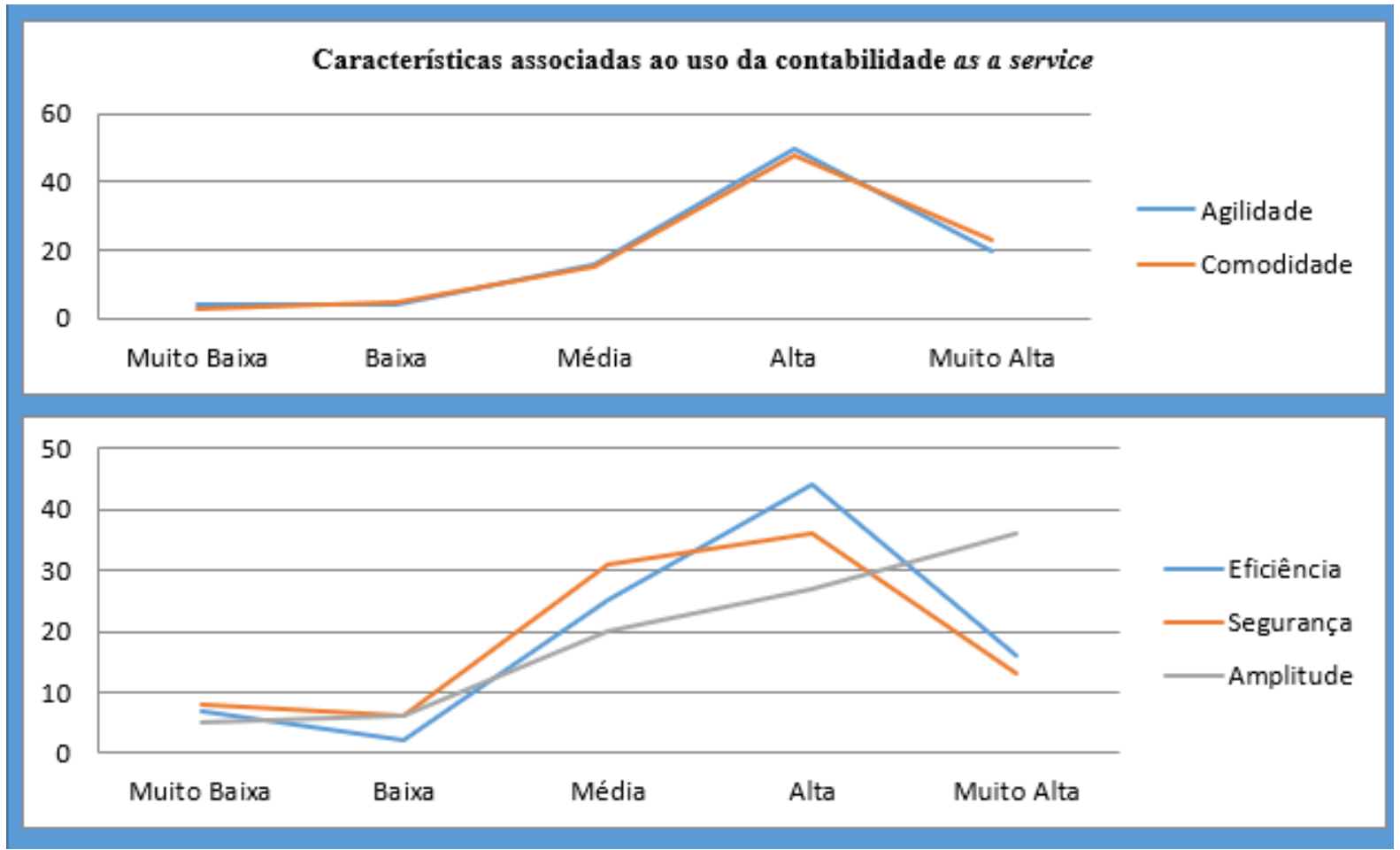


Pondo em evidência estas conotações, buscou-se aquilatar em campo qual a percepção dos contabilistas quanto as estes aspectos. Percebeu-se que os aspectos de comodidade e agilidade praticamente têm mesma percepção, devendo por isso, serem observados conjuntamente. Igual semelhança, mas com variações mais distanciadas surgiram sobre os aspectos de segurança e eficiência, conotando uma associação organizacional bem sistemática entre as duas grandezas. Por fim a grandeza amplitude foi percebida como aspecto crescente para a maioria dos respondentes e, portanto, configurou-se como aquela que pode assumir o papel de vetor da e para eventual migração para a modalidade as a service.

Entre os aspectos apurados então se delineou um mote para questionar qual a ação contábil (atividade de conhecimento e prática segmentada) desenhadas em textos (IUDICUBUS; MARION, 2006), qual aquela que tinha mais condições de sair da comodidade dos escritórios contábeis e de seu suporte de contabilidade online, para passar a figurar como contabilidade as a service, em nuvem, sob contrato, e na forma de conexão gerenciada.

O resultado que já era cogitado se analisadas as repostas prévias até aqui relatadas, indicou que aquele conjunto de atividades mais bem processualizado, regrado e que pode ser transposto para algoritmos lógicos e consistentes, como exposto na seção 3 deste texto, e que perfazem consistentemente a contabilidade financeira e a contabilidade gerencial (em menor escala), despontaram como aquelas potencialmente candidatas à migração imediata.

Em reforço, com mostrado no gráfico Io, as atividades mais cognitivas assumiram uma perspectiva de migração parcial. Assim, o caso parece mais bem retratado que no caso da contabilidade online em relação às atividades de controladoria, pericia e auditoria.

Gráfico IO - Indicativos para potencial migração de tipos de ações contábeis em escritórios.

Percepção quanto à possibilidade de migração para nuvem(as a service)

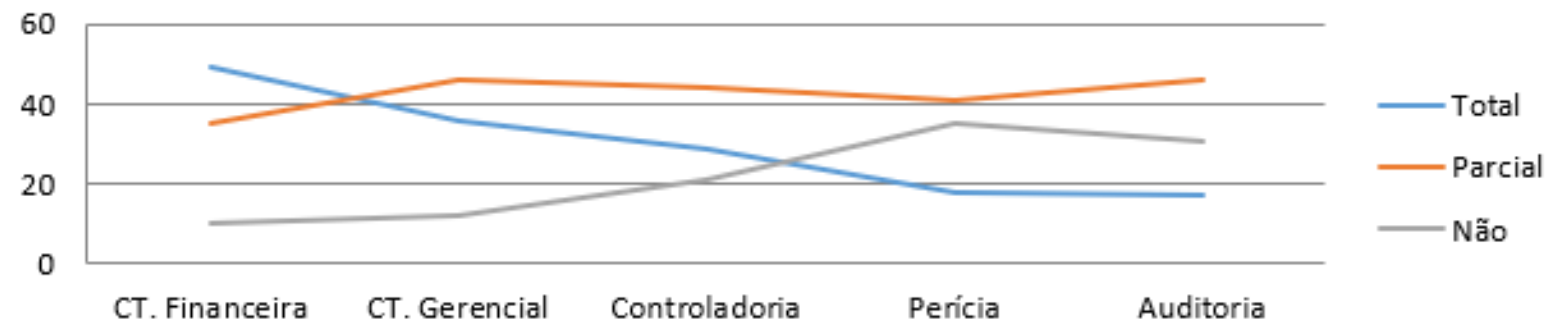

\subsection{Uma breve incursão qualitativa}

Por fim, em termos de fechamento da aplicação do questionário da pesquisa, foi feita uma questão aberta em termos de provocação velada, convidando os contadores a refletirem se a contabilidade as a service não se configurava como uma ameaça concreta à instituição escritório contábil e por extensão, pela cultura brasileira, a função (típica) do contabilista.

A expressiva maioria das respostas inclinou-se para o lado do não. Treze delas foram lacônicas, ofertando apenas o monossílabo apenas como resposta; "não". Outros foram mais sofisticados em suas negativas, a exemplo de: 
"Não acredito nisso, embora atualmente se ofereçam serviços mais baratos em sites do que em escritórios ou por mão de obra mais qualificada; acredito que os empresários tem medo de ver as informações sigilosas das suas empresas com pessoas que eles não conhecem ou tem relação contratual de forma comum no mercado". (Respondente 47).

Ou como deixou claro o Respondente I7: "não, atualmente já existem diversas empresas que utilizam essa ferramenta e mesmo assim necessitam de um contador. Essa ferramenta pode ser bastante útil no sentido de redução de custos, agilidade nos serviços prestados e segurança das informações".

Mas também houve aqueles mais taxativos, a exemplo do Respondente 58 que pregou que "não creio. Entendo que ainda há campo para o trabalho analítico", ou mesmo bravios como o Respondente II "logicamente não. Que pergunta sem cabimento foi essa?".

Quer se crer que no espaço futuro de análise qualitativa, mais elementos poderão sobrevir para ratificar o não ser possível extinguir escritório nem substituir talentos. Guarde-se o testemunhal muito bem articulado do Respondente 63, como incentivo à reflexão.

\footnotetext{
"Acredito que o serviço em nuvem apenas facilita a estrutura física para execução das rotinas. O trabalho de análise que só um contador com conhecimentos técnico e conhecimento conceitual das rotinas da empresa é algo fundamental e entendo que insubstituível não importa que tecnologias venham ainda com a subjetividade das interpretações das normas, acho muito difícil colocar em um sistema a capacidade de refletir e fazer julgamentos, sistemas funcionam por regras lógicas e a contabilidade é tem muita base julgamento reflexivo, por isso a grande importância da análise técnica que só um profissional capacitado é capaz de realizar". (Respondente 63).
}

Todavia algumas constatações pela opção sim, como uma situação aflitiva para escritórios e profissionais, poderiam ser exibidas como contraponto, entre elas são dignas de registro a do Respondente 74, "a tecnologia pode gerar algum programa que com o algoritmo certo, pode aos poucos ir fazendo as tarefas contábeis" ou algumas mais jocosas como a do Respondente 69 "se esta tecnologia trouxer benefícios, temos que nos adaptar a ela. Já nos adaptamos bastante desde o tempo do Guarda-Livros".

Resguardando como elemento para reagrupamento futuro um registro referente ao sim, pode-se destacar a menção do Respondente 29:

\footnotetext{
"Talvez sim, porém teria que realmente comprovar que as inovações tecnológicas são capazes de atender todas as demandas contábeis, uma vez que, existem atividades, como lançamentos contábeis, que vejo necessária a intervenção do profissional para que ela seja feita corretamente" (Respondente 29).
}

\section{Conclusão}

O presente relato teve como intento avaliar qual a percepção dos contadores em geral sobre a atividade desenvolvida usualmente nos escritórios contábeis em seus formatos online 
(pouco difundido) ou através da Internet (extremamente confundido com serviço online). A opção declarada nesta escuta era sondar se a computação em nuvem, cloud computing, e seus arsenais de aplicações as a service, estariam em tempo de utilização naqueles ambientes.

Em sendo destacado o uso, qual a seria a potencialidade, vantagens e ameaças ao que já está estabelecido nas rotinas daquelas organizações.

Inventariando-se a literatura de apoio, pode-se perceber de um lado que a chamada contabilidade financeira configura-se como bastante processualizada, bastante regrada e sob parâmetros rígidos de modelagem e execução. Em sendo assim, é potencialmente transponível para algoritmos, sistemas e aplicações, as quais executam sempre em feição online.

Este enredo se configurou na enquete e os contabilistas alcançados delinearam uma significativa aderência da contabilidade financeira - e de suas rotinas - e em menor escala da contabilidade gerencial, a tarefas executadas em ambiente de escritório contábil e em versão online.

Ato contínuo, buscou-se averiguar como se encarava no mesmo público e na mesma dimensão, os aspectos atinentes à computação em nuvem e à execução da contabilidade como uma rotina as a service, em especial na modalidade IaaS. Resgatou-se que se antevê como exequível parte significativa das rotinas básicas, aqui taxadas de tradicionais, no mesmo direcionamento da execução online e também aqui bem mais próximo à contabilidade financeira e gerencial.

Atividades a princípio mais elaboradas ou rebuscadas como controladoria, auditoria e perícia que embora também sejam fortemente regradas têm um peso cognitivo mais definido e um potencial analítico mais individualizado, tiveram repercussão menor, tanto na sistemática online quanto na sistemática em nuvem.

Por fim foram sondadas vantagens organizacionais de se ter a contabilidade as a service e os aspectos mais destacados foram de amplitude, agilidade e comodidade. A preocupação mais evidente foi relativizada em torno da segurança digital.

Adiante como perspectiva exploratória procurou-se saber qual seria a impressão atrelada à sucessão da entidade escritório contábil e do profissional contador, pelas rotinas as a service. Aqui o espírito defensivo do contador prevaleceu tanto para uma premissa quanto para a outra, com alguma condescendência evolutiva que mira, justamente, a parte mais automatizável (a contabilidade financeira) para uma migração mais imediata, em detrimento de outra não cogitável, a priori, para migração, aquela das atividades mais sofisticadas como perícia.

Ao cabo e ao fim, averiguou-se que a computação em nuvem é potencial substituta para parte das atividades dos escritórios contábeis, mas que precisa ainda ser mais bem trabalhada, pois prevalece, para os informantes a noção de que o talento do profissional contábil em decisão e julgamento ainda é algo inquestionável e insubstituível. 


\section{REFERÊNCIAS}

ALVES, F. L.; MIRANDA, L. C.; MEIRA, J. M.; CALLADO, A. L. C. (20I3). Uma Análise dos Escritórios de Contabilidade sobre a Necessidade de Aplicação das IFRS para Pequenas e Médias Empresas. Sociedade, Contabilidade e Gestão, Rio de Janeiro, v. 8, n. 3.

ARRAiAl, B. (20II). Cloud Computing, um desafio para Pequenas e Médias Empresas. Disponível em: http://www.tiespecialistas.com.br/20I//o4/cloud-computing-um-desafio-parapequenas-e-medias-empresas.

ATTARAN, M. (2004). Exploring the relationship between information technology and business process reengineering. Information \& Management, n. 4I, p. 585-596.

ATKINSON, A. A. et al. (2008). Contabilidade gerencial. 2.ed. São Paulo: Atlas.

BARROS, V. M. (2005). O novo velho enfoque da informação contábil. Revista Contabilidade e Finanças - USP, São Paulo, n. 38, p. IO2-II2, maio/ago.

BONINI, R. P. JUNIOR, E. A. O. (20I2). Um catálogo de tecnologias e ferramentas para o desenvolvimento de sistemas em nuvem. Disponível em: http://www.espweb.uem.br/wp/wpcontent/uploads/20I2/05/Rodrigo-Pereira-Bonini-Cloud-Computing.pdf.

BRASIL. Código Civil Brasileiro. (2002). Brasília. Disponível em: http://www.planalto.gov. br/ccivil/leis/2002/Lio406.htm. Acesso em: 30/04/20I6

CARDOSO, J. L. SOUZA, M. A. ALMEIDA, L. B. (2006). Perfil do contador na atualidade: um estudo exploratório. Revista BASE. p. 275-284.

COLANGELO FILHO, LÚCIO. (200I) - Implantação de Sistemas ERP. São Paulo, Ed. Atlas.

COMITÊ DE PRONUNCIAMENTOS CONTÁBEIS (20I5). Pronunciamento Conceitual Básico: Estrutura conceitual para elaboração e apresentação das demonstrações contábeis. Disponível em http://www.cpc.org.br/pdf/pronunciamento_conceitual.pdf.

COELHO, P.; SILVA, R. (2007). Um estudo exploratório sobre as metodologias empregadas em pesquisas na área de contabilidade no ENANPAD. ENANPAD. [S.1.]: [s.n.]

COLliS, J. HUSSEY, R. (2005). Pesquisa em Administração. 2a. Ed. São Paulo: Bookman.

COSTA, C. (20I4). Auditoria financeira: Teoria e prática (IO. ${ }^{a}$ Ed). Lisboa: Rei dos Livros.

DIAS, J. M. F.; RODRIGUES, R. C. M. C.; PIRES, D. F.; (20I2). A segurança de dados na computação em nuvens nas pequenas e médias empresas. Revista Eletrônica de Sistemas de Informação e Gestão Tecnológica. Vol. 2. n. I 
DUARTE, R. D. (20I6), Uma real inovação disruptiva no mundo contábil. Dispovível em: http://contaazul.com/contabilidade/blog/uma-real-inovacao-disruptiva-mundo-contabil/ Acesso em 20 de janeiro de 2016.

EQUIPE DE PROFESSORES DA FEA/USP. (I998). Contabilidade Introdutória. 9. Ed. São Paulo:Atlas.

ECKERT, A. VANI, F. MECCA, M. BIASIO, R. (20I5). Utilizando a assessoria do escritório contábil em micro e pequenas empresas: A percepção dos gestores. Revista de Administração e Negócios da Amazônia, V.7, n.I, jan/abr.

FEDEL, L. B. SCHUCK, S,. ZANCHET, A. (2009). A contabilidade terceirizada: uma análise dos serviços demandados pelas empresas e a sua satisfação com os escritórios contábeis. V Encontro Paranaense de Pesquisa e Extensão em Ciências Sociais e Aplicadas. Área: Ciências Contábeis. Cascavél.

FRANCO, H. MARRA, E. (1982). Auditoria contábil. São Paulo: Atlas.

FERNANDES, F.; (20I5). Modelo de Organização de Escritórios Contábeis: Qual é o mais adequado? Disponível em: https://www.nibo.com.br. Acesso em: 13/02/2015.

FIGUEIREDO, S.; FABRI P. (2000). Gestão de empresas contábeis. São Paulo: Ed. Atlas.

FONSECA, C; MEIRELLES, F \& DINIZ, E (20I0). Tecnologia Bancária no Brasil: uma história de conquistas, uma visão de futuro. Rio de Janeiro: FEBRABAN.

GIL, A. C. (20I0). Como elaborar projetos de pesquisa. $4^{\text {a }}$. ed. São Paulo: Atlas.

GARISSON, R.; NOREEN, E.W; BREWER, P.C. (20I3). Contabilidade Gerencial. I4 ed. McGraw-Hill.

GUIMARÃES, L. A. M.; MARTINS, D. A.; GUIMARÃES, P. M. (2004). Os métodos qualitativo e quantitativo: similaridades e complementaridade. Método qualitativo: epistemologia, complementaridade e campos de aplicação. São Paulo: Vetor, p. 79-9I.

GODOY, A. S. (I995). Introdução à pesquisa qualitativa e suas possibilidades. Revista de Administração de Empresas. v. 35, n. 2, p. 57-63.

HERNANDES, A. (2015). Como Montar um Escritório de Contabilidade Online. Disponível em: https://www.youtube.com/watch?v=mdWwojzkH_A

HOOG, W. A. Z (2009). Perícia contábil. 4. ed. São Paulo: Atlas.

HANSEN, D. R.; MOWEN, M. M. (1997). Cost management. $2^{\text {a }}$ ed. Cincinnati, Ohio: SouthWestern College Publications. 
IUDÍCIBUS, S. MARION, J. C. (2006). Introdução à Teoria da Contabilidade. $4^{\mathrm{a}}$ ed. São Paulo, 2006.

KAUARK, F.; MANHÃES, F.C; MEDEIROS, C.H. (20I0). Metodologia da pesquisa: guia prático. Itabuna: Via Literarum.

KARTHIKEYAN, N. SUKANESH, R.(2OI2). Cloud based emergency health care information service in India. Journal of medical systems.

LAUDON, K. LAUDON, J. (20I5). Sistemas de Informações Gerenciais. II ${ }^{\mathrm{a}}$ ed. São Paulo: Thomson-Learning.

LAURENTINO, A. J.; LESTENSKY, D. L. NOGARA, J.G. PRIA, T.D. (2008). A importância da contabilidade gerencial para as micro e pequenas empresas no século XXI no Brasil. 76f. Monografia (Ciências Contábeis) - FAE Centro Universitário. Curitiba.

LUNARDI, G.; DOLCI, P.; MAÇADA, A. (20I0). Adoção de tecnologia de informação e seu impacto no desempenho organizacional: um estudo realizado com micro e pequenas empresas. Revista de Administração de Empresas. v.45, n.I, p.05-I7.

MARION, J.C. (2009). Contabilidade Básica. Io ed. São Paulo: Ed. Atlas.

MEDEIROS, T. (20I2). Estudo sobre a percepcão dos empresários das microempresas e empresas de pequeno porte sobre as demonstrações contábeis fornecidas pelos profissionais de Contabilidade no município de Campina Grande. Departamento do curso de Ciências Contábeis da UEPB. Campina Grande.

MELL, P.; GRANCE, T. (2009). The NIST definition of cloud computing. Disponível em: http://www.newinnovationsguide.com/NIST Cloud Defi nition.pdf

MERRIAM, S. B. (I998). Qualitative research and case study applications in education. São Francisco (CA): Jossey-Bass.

NEVES, S. VICECONTI, P. E. V. (I998). Contabilidade de custos: um enfoque direto e objetivo. 5.ed. São Paulo: Frase.

PADOVEZE, C. L. (2004). Estruturação do sistema de informação contábil no ERP. XXIV Encontro Nacional de Eng. de Produção - Florianópolis - Brasil, novembro de 2004.

PETERS, M. R. S. (2004). Controladoria Internacional: Incluindo Sarbanes Oxley Act e USGAAP. São Paulo: DVS Editora.

PRODANOV, C. C. DE FREITAS, E. C. (20I3). Metodologia do Trabalho Científico: Métodos e Técnicas da Pesquisa e do Trabalho Acadêmico - $2^{\text {a }}$ Ed. Editora Feevale.

PRADO, E. P. V.; BRITO, B. A. S. (20I0). Barreiras Na Implantação de Sistemas de 
Informação em Escritórios Contábeis. XII Semead, São Paulo, Setembro 2010.

PRADO, E. P. V.; BRITO, A. S. B; CRISTIANI, G. (20I2). Adoção Da Computação Em Nuvem Em Micro E Pequenas Empresas: Um Estudo Sobre Escritórios Contábeis. $9^{\circ}$ CONTECSI. São Paulo. USP.

RAMALHO, N. C. R. (20I2). Um estudo sobre a adoção da computação em nuvem no Brasil. São Paulo.

REIS, E. (200I). Estatística Multivariada Aplicada. Lisboa: Sílabo.

RICINI, C.; ZANCHET, A. (2008). Fatores determinantes nas decisões de terceirização dos serviços contábeis das empresas da cidade de Palotina -PR. In: VII SEMINÁRIO DO CENTRO DE CIÊNCIAS SOCIAIS APLICADAS - CASCAVEL.

RIBEIRO, A. FREIRE, E. BARELLA, L. (20I3). A informação contábil como instrumento de apoio às micro e pequenas empresas: percepção dos gestores de micro e pequenas empresas de Paranaíta-mt, quanto à utilização de informações da contabilidade no processo de tomada de decisão, no ano de 20I2. Revista REFAF. vol. 3 n. I, 2013

SANTOS, Marcelo. (20I6). Blog Conta Azul para Contadores. Disponível em: http://contaazul. com/contabilidade/blog/como-montar-um-escritorio-de-contabilidade-online/

SPLITTER, K. BORBA, J. A. (20I4). Percepção de estudantes e professores universitários sobre a profissão do contador: um estudo baseado na teoria do estereótipos. Revista de Educação e Pesquisa em Contabilidade. Brasília, v.8, n.2. p. I26-I4I.

SÁ, A. L. (2002). Curso de auditoria. Io. Ed. São Paulo: Ed. Atlas.

SÁ, A. L. (2009). Perícia Contábil. $8^{\text {a }}$ Ed. São Paulo: Ed. Atlas.

SOUZA, E. M. C; SANTOS, R. T; (2005). A Contabilidade como Ferramenta de Controle Disponível em: http://www.classecontabil.com.br/artigos/a-contabilidade-como-ferramenta-decontrole. Acessado em: 25/08/20I5.

TAURION, C. (2009). Cloud Computing: Computação em Nuvem transformando o mundo da tecnologia. Rio de Janeiro: Brasport.

THOMÉ, I. (200I). Empresas de serviços contábeis: estrutura e funcionamento. São Paulo: Ed. Atlas.

VERAS, M. (20I2). Cloud Computing: Nova arquitetura de TI. São Paulo: Brasport.

VERDERAMI, B. M. ROSA, R. (2013). Avaliando O Uso Da Computação Em Nuvem Na Ti Para Pequenas E Médias Empresas Brasileiras. Revista Computação Aplicada, v. 2, n. I. 
VIEIRA, C. S; MEIRELLES; F. S. (20I5). Computação em Nuvem: Análise bibliométrica da produção científica sobre os fatores que influenciam as empresas no seu uso. Rev. Eletrônica Gestão e Serviços V.6, n.2, Jul./Dez.

YIN, R. K. (20I3). Case study research: Design and methods. Sage publications.

ZWIRTES, A. ALVES, T. W.(2015). Os Impactos Causados pela Inovação Tecnológica nos Escritórios de Contabilidade do Rio Grande do Sul: Uma Análise de Cluster. Revista Contraponto, Vol. I n. 3, out.nov. 